\title{
Determinants Influencing the Conversion of Financial Statements: The Case of Multinational Firms in Vietnam
}

\author{
Manh Dung TRAN*, Thi Tuyet Mai NGO**, To Uyen PHAN"** Duc Tai DO**** ${ }^{* *}$ Thi Thuy Hang PHAM ${ }^{* * * * *}$ \\ Received: December 19, 2019 Revised: January 29, 2020 Accepted: February 06, 2020
}

\begin{abstract}
The research aims to investigate the impact levels of determinants on the conversion of financial statements from Vietnamese accounting standards (VAS) to International financial reporting standards (IFRS) in the multinational firms in Vietnam. The method of data collection was done through the survey and subjects are accountants in Multinational Firms doing business in Hanoi and ten neighboring provinces. After checking the information on the votes, there are 170 questionnaires with full information for data entry and analysis. We use Cronbach's Alpha, EFA analysis and run regression model to investigate the impact levels of each independent variable on dependent variable of the conversion of VAS financial statements to IFRS. The results show that five determinants including Economic, Politics, Law, Culture, and Conditions for implementation have positive relationships with the conversion of VAS financial statements to IFRS. In particular, Economic determinant is the most strongest. Based on the findings, some recommendations are given for improving the conversion of VAS financial statements to IFRS of multinational firms doing business in the context of Vietnam. The results are considered a useful reference for firms when making financial statements to transparently change the financial statement information and improve the quality of financial statement information.
\end{abstract}

Keywords : Financial Statements, IFRS, Vietnamese Accounting, Multinational Firms

JEL Classification Code: M40, M41, O15

\section{Introduction}

Nowadays, there are about 130 countries in the world applying IFRS in different forms. Implementation of IFRS can enhance the quality of financial reports, in turn improving their ability and usefulness (Carlin, Finch, \& Tran, 2014). Vietnam is one of the unregulated countries

*First Author. Associate Professor, National Economics University, Vietnam. Email: manhdung@ktpt.edu.vn

**Associate Professor, School of Trade and International Economics, National Economics University, Vietnam.

Email: ngothituyetmai@neu.edu.vn

${ }_{* * \star}$ Associate Professor, School of Trade and International

Economics, National Economics University, Vietnam. Email: uyenpttmai@gmail.com

${ }^{* * * *}$ Corresponding Author. Lecturer, Department of Accounting, University of Labor and Social Affairs, Vietnam [Postal Address: No. 43, Tran Duy Hung road, Cau Giay district, Hanoi, 100000, Vietnam] Tel. +84904509101, Email: taiketoanquocte@gmail.com

*****Lecturer, Department of Economics, Vinh University, Vietnam. Email: thuyhang1983tc@gmail.com

(c) Copyright: The Author(s)

This is an Open Access article distributed under the terms of the Creative Commons Attribution NonCommercial License (https://creativecommons.org/licenses/by-nc/4.0/) which permits unrestricted noncommercial use, distribution, and reproduction in any medium, provided the original work is properly cited.
IFRS. However, in the near future, Vietnam is going to prepare a road map for applying IFRS. The role that multinational firms play has become more and more crucial in global economy, as well as in the encouragement of global economic growth and development. They motivate economical development in many countries, especially less developed ones, through the equity, technology, or administrative abilities that these firms brought to the host countries whose investments they benefited from. Via their factories and projects in low and middle income countries, multinational firms are deemed to have contributed to the creation of jobs, the increase of gross domestic product (GDP), as well as the advancement of scientific, technological and administrative capabilities in the said countries. Via their performance, they are also able to assist the host countries by changing their economical structure, increasing their import and export, and further integrating the host countries into the global economy.

Accounting standards applied in Vietnam are including but not exclusive to Vietnamese accounting standards (VAS); Corporate Accounting regulations (circular, regulations, etc.) and Accounting Law. The International Financial Report Standards (IFRS) are also applied in Vietnam. Multinational firms in the country are often seen 
adopting the same accounting software as their parent firm, which follow IFRS. The reports, after extracted would be converted into Vietnam's eligible formats. The opposite goes for the filings, which happened under Vietnam's format and converted into the firm's standards. Therefore, to meet the request for information, managing and operating on a wide range, compliance with the law, the conversion of VAS financial statements to IFRS is one of the urgent requirements. In addition, determinants influencing the conversion of VAS financial statements to IFRS needs to be analyzed, measured and explained in detail.

Based on the results of previous studies, we continue analyzing, measuring determinants influencing the conversion of VAS financial statements to IFRS in different sample scales. We also give some recommendations in order to improve the conversion of VAS financial statements to IFRS in Multinational firms in the context of emerging countries like Vietnam.

\section{Literature Review}

In the world, there have been studies on determinants influencing the conversion of financial statements from National accounting standards to IFRS, notably as:

\subsection{Economic Factor}

The business environment in multinational firms is more complex than that in domestic ones. The globalization of the market economy and the financial market requires an economic environment in which uniform regulations for financial statements will benefit not only investors, creditors, financial analysts but also process such as accounting and auditing. The homogeneity of accounting standards makes it easier to compare financial statements in firms in different countries (Smith \& Runyan, 2007). Studying the use of IFRS in Nigeria, Madawaki (2012) concluded that the switch to IFRS would attract foreign investors, reduce the cost of converting financial statements to IFRS for firms, create favorable conditions for listed firms on the regional and world stock markets.

\subsection{Legal Factor}

There are many challenges when converting to and using IFRS, the differences between Finnish accounting law and IFRS are largely due to Finnish law and Danuta-based rules (Krzywda \& Schroeder, 2007). According to Krzywda and Schroeder (2007), in order to be able to use IFRS, Finland needs to develop accounting rules based on regulations other than principles. Countries need to make national accounting policies to use IFRS; need to consider, evaluate and solve all difficulties and obstacles before converting to and using IFRS (Shima \& Yang, 2012).

\subsection{Cultural Factor}

Aisbitt (2006) collected financial statements according to UK GAAP and IFRS published by 100 listed firms on the UK stock market to analyze the impact of capital and the impact of GAAP, comparing the impact of GAAP and the impacts of individual standards on the conversion of GAAP to IFRS in these firms. The results show that the influence of capital is non-material but the influences caused by "habits" have notable consequences on financial analysis and compliance responsibilities. The level of difference between firms depends on the requirements of the users of financial statements. Demaria and Dominique (2008) conducted research at French firms on the choice between original price and market price for asset assessment, applying four standards which are: IFRS1: First-time Adoption of IFRS; IAS16: Property, Plant and Equipment; IAS38: Intangible assets; IAS40: Investment properties. Demaria and Dominique (2008) argue that these firms use the original price according to prudent choices and that cultural factors affect the conversion to and the use of IFRS when preparing financial statements because of the influence of habits and prudent choices.

\subsection{Political Factor}

Ramanna (2013) analyzes the political elements of international convergence through analysis in Canada, China and India. According to Ramanna (2013), each country has different strategies in the process of convergence depending on its political position. Countries that have a powerful political position will find way to influence IASB to converge in a way that is favorable to their country.

\subsection{Factor of Conditions for Implementation}

Barth (2008) showed that there are many challenges and opportunities when converting financial statements to IFRS when it comes to training, research at schools and training the force of accounting staff with IFRS knowledge in firms. Teller (2009) studies the financial statements of 150 firms in France with the following assumptions: the firm prefers to choose the exceptions that bring good or bad results, affecting capital on the date of conversion, offsetting with the impact on capital caused by mandatory adjustment under IFRS, mandatory adjustment of capital under IFRS is more valuable than French GAAP and analysis on factors such as market price or original price, employee benefits, 
cumulative difference on the date of conversion, previous record of financial instruments, business consolidation. The way to motivate managers to apply IFRS, the value brought along with the exemption decisions when first adopting IFRS, the value effects of mandatory and capital adjustment options must be noted as the outcomes of the first-time adoption of IFRS. Research results show that: Compulsory adjustment of capital brings higher value than French GAAP; the influence of the administrator's strategic decision on one or more exceptions on the IFRS conversion date; the value of the capital adjustment under IFRS depends on the published results of the new information.

In Vietnam, Nguyen (2014) analyzes and systematizes the theoretical bases related to factors affecting the application of IFRS in Vietnam. Research results show that cultural factors, economic growth, and international economic integration strongly influence the application of IFRS; capital market and law are two factors affecting the application of IFRS in Vietnam. From that, he has made recommendations to competent authorities, businesses and other subjects to improve the application of IFRS in Vietnam. Do and Tran (2017), affirmed that cultural factors affect the discrepancies in financial statements of foreigninvested firms according to Vietnamese accounting and international accounting standards. Do and Tran (2017) make recommendations to reduce discrepancies to attract foreign investment such as authority agencies need to improve the role of accounting professional organizations, accounting professional organizations has the roles in participating in the development of legal documents in the field of accounting.

In addition, there have been studies on the conversion of financial statements from national accounting standards to IFRS, such as:

Eva and Sylwia (2007) studied the first implementation of IFRS for European' Listed companies. They conclude that there are several problems when converting financial statements into IFRS such as benefits and costs during converting. Another study by Eva, Alan, and Natalie (2014) identifies that the entries need to be adjusted when converting the financial statements from GAAP of the US to IFRS, discuss the important indicators were affected by the conversion of financial statements. This study shows that the transition to IFRS is problematic. The transition to IFRS provides many opportunities for the financial structure of the firm, helping to see the critical assessments of experts when applying the rules of the IFRS.

Struharo (2010) studied the conversion of financial statements from national accounting standards to IFRS for companies in the Czech Republic. The author presented the reasons for conversion and issues related to conversion of financial statements to IFRS. The research results show that converting the financial statements to IFRS affects the information on the financial statements and relates to the financial situation of the firm.

In short, determinants influencing the conversion of national accounting standards financial statements to IFRS which have been published include: Economic integration, Legal system, Culture that affects the application of IFRS. Studies are conducted in developed countries, which have many different characteristics of economy, politics, culture and society from Vietnam. However, many of these studies use qualitative research methods, which do not measure the degree of influence of each factor on converting financial statements to IFRS.

Although previous studies have used both qualitative and quantitative research methods, they still have certain limitations on the size and sample of research, limitations on the adequacy of research results and discussion. In addition, there have been studies in Vietnam related to this research topic, such as Nguyen and Nguyen (2020); Nguyen and Lam (2017); Nguyen (2018); Vo, Ha, and Bui (2018). Mizutani (2016) showed that, for donors, financial statements are main source of accounting information. Besides, the research scope is multinational corporations, Yoon, Kim, and Eom (2019) asserted, the task crafting and cognitive crafting of multinational employees were shown to have an influence on career attitude, but relation crafting did not have any impact on career. Based on the above studies, this study employs a mixed research method to analyze, evaluate and measure factors affecting the conversion from Vietnamese accounting standards to IFRS in multinational firms in Vietnam; focus on presenting recommendations according to the most influential factors in order to make it more convenient and easier for multinational firms in Vietnam to convert from Vietnamese accounting standards to IFRS.

\section{Theoretical Background}

\subsection{Usefulness Theory}

Usefulness theory is an important basis for selecting information provided in financial statements (Staubus, 2000). Chalmers and Godfrey (2004) stated that usefulness theory refers to the effect of benefits and costs, which is the managers' concern in converting the financial statements to IFRS. The balance between the costs and benefits of IFRS conversion and IFRS adoption will affect the managers' decision because companies' management considers that converting the financial statements into IFRS can significantly affect the overall operation. A firm's conversion costs can outweigh the benefits. Therefore, this theory is not only related to the conversion of financial statements, but also to the factors that facilitate the 
organization of the implementation (the decision of the managers), the economic factor (world economic integration).

\subsection{The Theory of Culture's Consequences}

Theory of culture's consequences was developed by Hofstede (1980) to identify elements in different cultures. Gray (1988) has based on the cultural factors of Hofstede (1980) to develop the theory of culture's consequences which influence to the development of international accounting such as: Uniformity and flexibility. Cautious and optimistic, Confidentiality and transparency, etc. Thus, theory of culture's consequences is related to the conversion of financial statements to IFRS. On the other hand, Vietnamese accounting standards (VAS) currently promote regulations, compliance and stereotypes, etc. Vietnamese culture imbues with the cultures of Southeast Asian countries; therefore, this theory is relevant to cultural and legal factors.

\subsection{Theory of Legitimacy}

Theory of legitimacy is based on the idea of a social contract between a firm and society. Meeting the requirements of this contract, the firm is considered legal. The firm must make an annual report according to the requirements of this contract (Shocker \& Sethi, 1974). Applying legal theory to evaluate the benefits of financial statements according to IFRS as transparent, improving the quality, thereby contributing to attracting domestic and foreign investors; assess the difficulties and challenges of converting the financial statements into IFRS, including the provisions of specialized laws and accounting laws. Thus, Theory of legitimacy related to the conversion of financial statements and factors affecting the conversion of financial statements such as economic factors and legal factors.

\section{Research Methodology}

In order to achieve the objectives of this paper, we based on the theory of previous studies and the results of qualitative research through expert interviews and model analysis. On the other hand, we combined with the inductive method to verify, based on qualitative research results, to adjust and add observation variables to the questionnaire for conducting quantitative research.

Inheriting the results of research by, Aisbitt (2006), Smith and Runyan (2007), Krzywda and Schroeder (2007), Barth (2008), Demaria and Dominique (2008), Teller (2009), Ramanna (2013), Madawaki (2012), and Shima and Yang (2012).
Table 1: Determinants and Its Coding

\begin{tabular}{|c|c|}
\hline Code & Scale \\
\hline \multicolumn{2}{|r|}{ Economic (E) } \\
\hline E1 & $\begin{array}{l}\text { Vietnam has integrated more widely and deeply into the } \\
\text { world economy }\end{array}$ \\
\hline E2 & $\begin{array}{c}\text { Vietnam's capital market is fledgling, not yet attractive to } \\
\text { foreign investors. }\end{array}$ \\
\hline E3 & $\begin{array}{l}\text { Quality of information on financial statements according to } \\
\text { Vietnamese accounting standards (VAS) is still low; there } \\
\text { have been many discrepancies between financial statements } \\
\text { using VAS and that using IFRS. }\end{array}$ \\
\hline E4 & $\begin{array}{l}\text { One advantage for multinational firms in Vietnam that is } \\
\text { listed on the regional and world stock market is financial } \\
\text { statements being converted to IFRS. }\end{array}$ \\
\hline E5 & $\begin{array}{c}\text { Requirements for determining the financial value of } \\
\text { enterprises to promote M\&A activities for international } \\
\text { financial operations }\end{array}$ \\
\hline \multicolumn{2}{|r|}{ Politics (P) } \\
\hline $\mathrm{P} 1$ & Government intervenes deeply in accounting. \\
\hline P2 & $\begin{array}{l}\text { Information on financial statements of multinational firms } \\
\text { has not been fully and timely disclosed. }\end{array}$ \\
\hline P3 & $\begin{array}{l}\text { The administrative procedures related to accounting for } \\
\text { multinational firms are still complicated. }\end{array}$ \\
\hline P4 & $\begin{array}{l}\text { There exists many limitations on state management } \\
\text { authorities on accounting. }\end{array}$ \\
\hline P5 & $\begin{array}{l}\text { The Ministry of Finance is the main authority to draft and } \\
\text { promulgate Vietnamese accounting standards. }\end{array}$ \\
\hline \multicolumn{2}{|r|}{$\operatorname{Law}(L)$} \\
\hline L1 & $\begin{array}{l}\text { Some current regulations on corporate accounting are not } \\
\text { uniform. }\end{array}$ \\
\hline L2 & $\begin{array}{l}\text { The current regulations on the field of corporate accounting } \\
\text { are not clear and general. }\end{array}$ \\
\hline L3 & $\begin{array}{l}\text { Vietnam's regulations related to accounting are different } \\
\text { from the recent international financial report standards. }\end{array}$ \\
\hline L4 & $\begin{array}{l}\text { Vietnam lacks some accounting standards corresponding to } \\
\text { international financial statements standards and accounting } \\
\text { regulations guiding the application of international financial } \\
\text { report standards. }\end{array}$ \\
\hline L5 & Tax law has a significant influence on accounting. \\
\hline \multicolumn{2}{|r|}{ Culture (C) } \\
\hline $\mathrm{C} 1$ & Psychological fear of risk and change in Vietnamese culture. \\
\hline $\mathrm{C} 2$ & Find ways to evade new things. \\
\hline $\mathrm{C} 3$ & $\begin{array}{c}\text { Viewpoint of not liking transparency, publicity, information } \\
\text { sharing. }\end{array}$ \\
\hline $\mathrm{C} 4$ & The role of professional associations is still limited. \\
\hline $\mathrm{C} 5$ & Lack of loyalty, comparing firms to find other jobs. \\
\hline \multicolumn{2}{|r|}{ Conditions for implementation (CFI) } \\
\hline CFI1 & Consensus from senior executives in the firm \\
\hline CFI2 & Funding support from corporate executives \\
\hline CFI3 & The level of information technology application of the firm \\
\hline CFI4 & Good English ability to use IFRS materials of accountants \\
\hline CFI5 & $\begin{array}{l}\text { The understandings of accountants in Vietname accounting } \\
\text { standards and IFRS }\end{array}$ \\
\hline CFI6 & Experience of accountants \\
\hline CFI7 & Responsibility for the job assigned of accountants \\
\hline
\end{tabular}


Nguyen (2014), Do and Tran (2017), Staubus (2000), Chalmers and Godfrey (2004), Hofstede (1980), and Shocker and Sethi (1974) using qualitative research approach through interviews with experts to perform quantitative research, we identify five determinants that affect the conversion of VAS financial statements to IFRS, i.e. Economic (E), Politics (P), Law (L), Culture (C) and Conditions for implementation(CFI).

Then, we conducted a questionnaire consisting of 27 observation variables with a 5-point Likert scale. Independent variables are measured from 1 "without effect" to 5 "strongly". The method of data collection was done through the survey and subjects are accountants in Multinational Firms doing business in Hanoi and ten neighboring provinces.

We sent 250 questionnaires and received the feedback of 200. After checking the information on the votes, there are 170 questionnaires with full information for data entry and analysis, the size of this sample is consistent with study of Hair et al. (2006) $(\mathrm{n}=50+8 \times \mathrm{m}=50+8 \times 5=90)$. Therefore, the rest of observations for model 1 are 170 surveys, including $100 \%$ participants who are chief accountants, general accountants and Multinational Firms in Vietnam's staff accountants. Participants mostly have Bachelor degree or higher $(100 \%)$. As can be seen, all participants are at high quality of accounting knowledge, and this makes surveys' answer are reliable.

We employ EFA analysis and regression model to investigate the impact levels of determinants on the conversion of VAS financial statements to IFRS.

Dependent variable: The conversion of VAS financial statements to IFRS (CFS).

Independent variable: The independent variables are described in Table 1.

From the above analysis, we have designed a research model as shown in Figure 1.

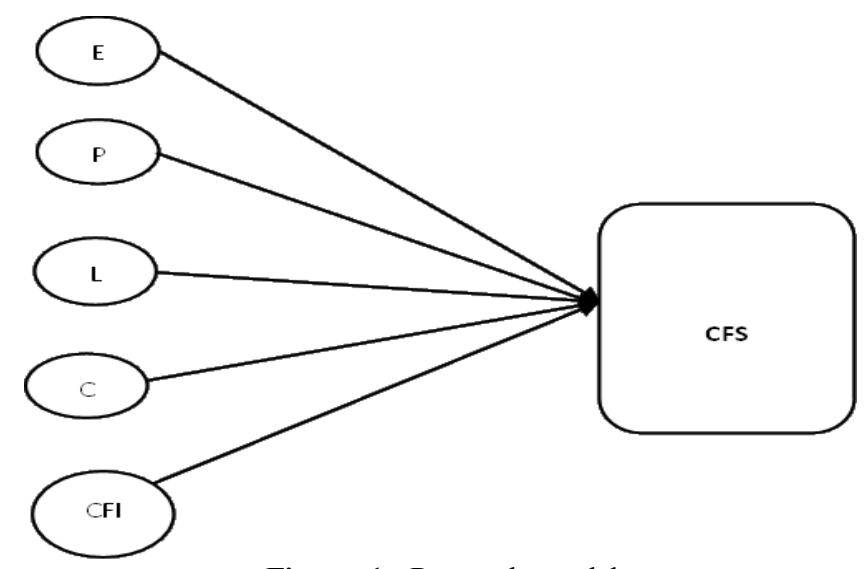

Figure 1: Research model

\section{Research Results}

\subsection{Descriptive Statistics}

Table 2 shows that among the 170 respondents, male accounted for $20.6 \%$, while the remaining 135 were Female, accounted for $79.4 \%$. Of these, 170 respondents, of which 77 with accounting staff, accounted for $45.3 \%$; 59 with General accounting, accounted for $34.7 \%$, Chief accountant accounted for $20.0 \%$.

Table 2: Respondents by gender, job

\begin{tabular}{|c|c|c|c|}
\hline & Frequency & Percent & $\begin{array}{c}\text { Cumulative } \\
\text { Percent }\end{array}$ \\
\hline \multicolumn{4}{|c|}{ Gender } \\
\hline Male & 35 & 20.6 & 20.6 \\
\hline Female & 135 & 79.4 & 100.0 \\
\hline \multicolumn{4}{|c|}{ Job description } \\
\hline General accountants & 59 & 34.7 & 34.7 \\
\hline Chief accountants & 34 & 20.0 & 54.7 \\
\hline Accounting staff & 77 & 45.3 & 100.0 \\
\hline Total & $\mathbf{1 7 0}$ & $\mathbf{1 0 0 . 0}$ & \\
\hline
\end{tabular}

\subsection{Cronbach's Alpha}

By using scale analysis, it can eliminate inconsonant variables and reduce errors in the research model. Therefore, only variables which have total correlation coefficients (Corrected Item - Total Correlation) greater than 0.3 and Cronbach's Alpha coefficients equal or greater than 0.6 are accepted (Hair, Black, Babin, \& Anderson, 2009). By analyzing Cronbach's Alpha analysis of determinants have an influence on the conversion of VAS financial statements to IFRS ( 5 determinants with 27 observed variables), the result is presented in Table 3 .

Table 3: Results of Reliable Testing

\begin{tabular}{|c|c|c|c|}
\hline Determinants & $\mathbf{n}$ & $\begin{array}{c}\text { Cronbach's } \\
\text { Alpha }\end{array}$ & $\begin{array}{c}\text { Corrected } \\
\text { Item-Total } \\
\text { Correlation }\end{array}$ \\
\hline Economic (E) & 5 & .864 & .558 \\
\hline Politics (P) & 5 & .754 & .350 \\
\hline Law (L) & 5 & .780 & .428 \\
\hline Culture (C) & 5 & .690 & .360 \\
\hline $\begin{array}{c}\text { Conditions for implement } \\
\text { ation (CFI) }\end{array}$ & 7 & .739 & .393 \\
\hline
\end{tabular}

The results also showed that all attributes had a Cronbach's Alpha coefficient greater than 0.6; the correlation coefficient of all attributes was greater than 0.3 , so all the attributes were statistically significant. 


\subsection{Exploratory Factor Analysis (EFA)}

We then conducted Exploratory Factor Analysis (EFA) where the method of extracting coefficients were component and Varimax analyses of the 27 observed independent variables. As can be seen in Table 4, the results of the EFA show that $0.5<\mathrm{KMO}=0.814<1$. Bartlett's testimony shows sig. $=0.000<0.05$, which means that all variables are interrelated.

After implementing the rotation matrix, 5 determinants with factor load factor are greater than 0.5; Eigenvalues are greater than 1; the variance explained is $62.310 \%$. It demonstrates that research data analyzing factor discovery is appropriate. Through the quality assurance of the scale and the test of the EFA model, identify 5 determinants influencing the conversion of VAS financial statements to IFRS.

Table 4: KMO and Bartlett's Test

\begin{tabular}{|c|c|c|}
\hline \multicolumn{2}{|c|}{$\begin{array}{c}\text { Kaiser-Meyer-Olkin Measure of Sampling } \\
\text { Adequacy. }\end{array}$} & .814 \\
\hline \multirow{3}{*}{$\begin{array}{c}\text { Bartlett's Test of } \\
\text { Sphericity }\end{array}$} & Approx. Chi-Square & $2,437.747$ \\
\cline { 2 - 3 } & Df & 351 \\
\cline { 2 - 3 } & Sig. & 0.000 \\
\hline
\end{tabular}

\subsection{Regression Model Analysis}

Based on adjusted model after the exploratory factor analysis, we have a multiple regression model:

$$
\mathrm{CFS}=\alpha+\beta \neg 1 \mathrm{E}+\beta 2 \mathrm{P}+\beta \neg 3 \mathrm{~L}+\beta 2 \mathrm{C}+\beta \neg 3 \mathrm{CFI}
$$

Table 5: Model Summary ${ }^{\mathrm{b}}$

\begin{tabular}{|c|c|c|c|c|c|}
\hline Model & $\mathbf{R}$ & $\begin{array}{c}\mathbf{R} \\
\text { Square }\end{array}$ & $\begin{array}{c}\text { Adjusted } \\
\mathbf{R} \\
\text { Square }\end{array}$ & $\begin{array}{c}\text { Std. } \\
\text { Error of } \\
\text { the } \\
\text { Estimate }\end{array}$ & $\begin{array}{c}\text { Durbin- } \\
\text { Watson }\end{array}$ \\
\hline 1 & $.813^{\mathrm{a}}$ & .660 & .650 & .31478 & 2.316 \\
\hline
\end{tabular}

a. Predictors (Constant): CFI, P, E, C, L

b. Dependent Variable: CFS

Table 6: Anova $^{\mathrm{a}}$

\begin{tabular}{|c|c|c|c|c|c|c|}
\hline & Model & $\begin{array}{c}\text { Sum of } \\
\text { Squares }\end{array}$ & Df & $\begin{array}{c}\text { Mean } \\
\text { Square }\end{array}$ & $\mathbf{F}$ & Sig. \\
\hline 1 & Regression & 31.609 & 5 & 6.322 & 63.802 & $.000^{\mathrm{b}}$ \\
\hline & Residual & 16.250 & 164 & .099 & & \\
\hline & Total & 47.860 & 169 & & & \\
\hline
\end{tabular}

a. Predictors (Constant): CFI, P, E, C, L

b. Dependent Variable: CFS

Table 7: Coefficients ${ }^{\mathrm{a}}$

\begin{tabular}{|c|c|c|c|c|c|c|c|}
\hline \multirow{2}{*}{ Model } & \multicolumn{2}{|c|}{$\begin{array}{c}\text { Unstandardized } \\
\text { Coefficients }\end{array}$} & $\begin{array}{c}\text { Standardized } \\
\text { Coefficients }\end{array}$ & \multirow{2}{*}{ T } & \multirow{2}{*}{ Sig. } & \multicolumn{2}{c|}{$\begin{array}{c}\text { Collinearity } \\
\text { Statistics }\end{array}$} \\
\cline { 2 - 3 } & B & Std. & Beta & & & Tolerance & VIF \\
\hline (Constant) & 1.236 & .280 & & 4.417 & .000 & \\
\hline E & .730 & .047 & .826 & 15.553 & .000 & .733 & 1.364 \\
\hline P & .115 & .046 & .051 & 1.516 & .013 & .575 & 1.740 \\
\hline L & .039 & .050 & .190 & 3.764 & .006 & .486 & 1.858 \\
\hline C & .031 & .050 & .162 & 3.625 & .005 & .814 & 1.228 \\
\hline CFI & .029 & .049 & .272 & 4.588 & .010 & .970 & 1.030 \\
\hline
\end{tabular}

a. Dependent Variable: CFS

Results of Tables 5, 6, 7 show that:

Multicollinearity testing: all variance inflation factor (VIF) of independent variables are under 2, so multicollinearity of model is low (Hoang \& Chu, 2008). Therefore, this regression model does not have any violation of the CLRM basic assumption.

Durbin - Watson statistic which is used to test the autocorrelation of residuals presents the model does not violate when using multiple regression method because Durbin - Watson value is 2.316 (in the interval of 1 and 3). In other words, the model is indicated no autocorrelation of residuals (Hoang \& Chu, 2008).

ANOVA testing result: Level of significant (Sig.) $=0.000$ implies that multiple regression model is suitable with data. Coefficient of R2 (R Square) $=0.660$, which means $66.0 \%$ of the total variation in the conversion of VAS financial statements to IFRS will be explained by the regression model.

Research model result indicates that all independent variables Economic (E), Politics (P), Law (L), Culture (C) and Conditions for implementation(CFI) are significant (because Sig. $<0.05)$ to the conversion of VAS financial statements to IFRS.

Determinants have influences on the conversion of VAS financial statements to IFRS are presented in the following standardized regression model: 
$\mathrm{CFS}=.826 \times \mathrm{E}+.051 \times \mathrm{P}+.190 \times \mathrm{L}+.162 \times \mathrm{C}+.272 \times$ CFI

Research model result indicates that all independent variables Economic $(\mathrm{E})$, politics $(\mathrm{P})$, pháp luật $(\mathrm{L})$, culture (C) and Conditions for implementation (CFI) are significant (because Sig. $<0.05$ ) to the conversion of VAS financial statements to IFRS.

\section{Discussion and Implications}

\subsection{Economic Factor}

Countries that have used IFRS have pointed out that they are attracting more and more directly foreign investors. Foreign investment inflows increased sharply after those countries apply IFRS (Irvine \& Lucas, 2006). In agreement with this, Francis and Hannah (2010) noted that countries that started to use IFRS have a higher level of international finance market integration than before. Enterprises will attract the foreign investors, reduce the cost of converting financial statements from national accounting standards to IFRS and make it more favorable for them to list stocks on the regional and international stock market when they apply IFRS (Madawaki, 2012). Countries where firms use foreign loans will increase their ability to apply IFRS (Shima \& Yang, 2012). Applying IFRS increases accountability across countries and increases stock liquidity (Neel, 2017).

Current situation of Vietnam's economy: The economy is increasingly integrated with the international economy. The state economic sector still plays a key role in the economy. Vietnamese capital market is still fledgling, thus has not attracted many foreign investors; Vietnamese investors hardly depend on information from financial statements when making decisions. Vietnam's economic policy differs from other countries: FDI enterprises in general and multinational firms in Vietnam in particular with many different business lines. Inflation in Vietnam, despite being strictly controlled, is still quite high. The economy is affected by globalization: impact from International Monetary Funds, World bank, World Trade Organizations and multinational firms in Vietnam. The stock market in Vietnam has gradually developed but still difficult to analyze, capitalization of Vietnam's stock market is still low compared to that of other countries in the region.

The level of economic development, economic types of the country, the system of financial supply as well as VAS currently has many contents which are inconsistent with international practices, the market-oriented economy, the particularities of economic management policies, the gradual changes in development of economy, etc. all dominate the accounting system. Besides, the current regulations on financial management in Vietnam are not consistent with the requirements of reformation, the roadmap for financial management reform is still very slow. In addition, the enterprise accountants still have to provide information and develop in accordance with the growth of economy. Furthermore, the more integrated the economic is, the more requirements are required to meet international standards, accounting is no exception. However, while IFRS is updated continuously, VAS has not been fully updated to conform to IFRS. Moreover, there is no synchronization in the VAS reform in Vietnam. This is one of the reasons that make VAS different from IFRS, thus affecting the conversion of VAS financial statements to IFRS.

\subsection{Political Factor}

The Ministry of Finance has developed a roadmap for applying IFRS in Vietnam from voluntary to compulsory application. Therefore, on the one hand, Vietnam needs to overcome environmental obstacles to the application of IAS/IFRS to the extent possible, such as: Establishing a true, market economy; further strengthen the role of the private economy; It is necessary to choose the approach with IFRS that is suitable to specific conditions of Vietnam. The political system has made practical steps to overcome many restrictions on the State management agencies on accounting, improve the administrative procedures related to accounting for multinational companies; streamlining management apparatus at all levels; change the management method of State agencies accordingly.

Vietnam is continuing to renovate its political system at all levels towards streamlining, improving the effectiveness and efficiency of leadership, direction and administration. Renovating and consolidating the organizational structure associated with perfecting functions and tasks, improving the quality of the contingent of officials and public employees; clearly defining the relationship between the leadership collective and the individual in charge; powers go hand in hand with responsibilities and promote the responsibility of the head. Complete and strictly implement the mechanism of power control, prevent abuse of power, violate discipline and discipline. Besides, streamlining the organization and organizational structure continues to clearly identify the functions, tasks and modes of operation of organizations. Adjust the functions and tasks of the political apparatus at all levels to suit the practical situation and new requirements and tasks.

\subsection{Legal Factor}

The legal system is directly related to the disclosure of 
the firm's financial statements. In order to convert and use IFRS, it is necessary to develop the national accounting standards as well as documents on accounting to guide the application of IFRS (Madawaki, 2012; Shima \& Yang, 2012). Heterogeneity in the legal system of accounting is one of the influences on IFRS conversion and application (Zakari, 2014; Uzma, 2016); the motivation for firms to use IFRS is due to the legal requirements of state authorities (Mantzari, Sigalas, \& Hines, 2017). This factor is different from that of other countries in the world in the system of legal documents on accounting in Vietnam, including Vietnamese accounting standards and accounting regime.

Up to now, Ministry of Finance has issued 26 VASs and many circulars in order to guide Vietnamese accountants to integrate with international accounting standards step by step. Ministry of Finance has just stopped at the circular guiding the accounting regime. There is no comprehensive amendment related to the accounting standards system. Nguyen (2017) argued that, although there are many changes in the contents of the accounting regime through three versions, basically the accounting regime consists of four major contents: documents, accounts, bookkeeping and financial statements; the co-existence of accounting standards and accounting regime is a specificity of VAS. Pham (2016) said that the Accounting Law is still limited when compared with the setout requirements. The new accounting law of Vietnam only refers to financial statements but has not fully mentioned the consolidated financial statements, the level of mention is still sketchy. Accounting law does not stipulate the contents related to the conversion of financial statements of subsidiaries operating abroad to Vietnam at the end of the year, which serve the consolidation of financial statements before the publication of the reports. Accounting law does not fully mention the accounting methods of derivative financial instruments. Accounting law does not stipulate the contents related to accounting environment, social issues and sustainable development.

\subsection{Cultural Factor}

That of multinational firms, which operate with global culture, provide more and more transparent information than domestic firms may be due to risk aversion, change of information disclosure affecting financial statements (Taylor, 1996). Countries with low levels of risk aversion will accept the use of IFRS financial statements (Shima \& Yang, 2012). In order to use IFRS, it is necessary to develop appropriate regulatory systems to overcome national cultural issues (Zakari, 2014), national culture is still influential in explaining the difference in profit governance levels among countries when firms use IFRS (Gray, Kang, Lin, \& Tang, 2015).
Previous colony countries were strongly influenced by the accounting systems of the countries that dominated them. Vietnam was once French colony, thus the Vietnamese accounting system is heavily influenced by the French accounting system. Vietnam is a country with a culture of risk aversion, then accounting system is quite prudent, restricting judgments, requiring compliance with laws and regulations (Tran, 2013). On the other hand, corporate culture represents shared values and beliefs, which have an impact on judgments and evaluations (Patel, 2003).

\subsection{Factor of Conditions}

\subsubsection{Support of Administrators}

Administrators progressively support the use of IFRS (Turel, 2009). However, one of many challenges that developing countries and emerging economies are facing in converting to and applying IFRS is the decision of the administrators of the firm. The conversion of financial statements to IFRS in firms requires consensus and human resource support, as well as financial resources of senior managers in firm (Ocansey, 2014; Christense, Lee, Walker, \& Zeng, 2015).

\subsubsection{Using Information Technology}

$\mathrm{Mr}$. Vu - Oracle Vietnam Solution Architect said that, digital accounting will become the pillar to support commercial activities with customers, and connect more essential department of the business. The digital breakthrough in accounting will create new trends, specifically, firms will replace the services that accountants are currently performing with cloud services. Firms will replace accountants if they do not adapt to cloud technology. Jobs that are easy to automate and replace with the most software include: Manual accounting entry, bookkeeping, year-end financial reporting, business activity report, salary, financial analysis main.

Information technology for accountants: Information technology plays a leading role in the accounting information system. The application of information technology to the accounting work has three levels: Semiannual processing level; level of automation of accounting work; level of management automation. Regarding the automation level of accounting: This level is popular among enterprises in Vietnam, in this form, enterprises do accounting with accounting software, information technology has penetrated into many fields. Traditional accounting practices have been completely altered, particularly the way accounting data is handled by the role of information technology. In fact, IT has automated traditional accounting books. The accounting software package can come with a wide range of 
specialized features or a generic program that can be customized to suit the business operation of the business. Businesses often choose accounting software based on the scale of their operations and the number of users accessing the Accounts System.

\subsubsection{Accounting Factors}

The level of the accountants and the capacity of them depend on the accountants themselves. In addition, it depends on the enterprise that the accountant is working in. Education level of accountants in the research sample has university degree or higher, accounting qualification. Accountants trained by the training program of the universities, including knowledge of general education, Professional education knowledge including basic knowledge of the sector, Basic knowledge industry, industry knowledge. In addition, soft skills such as application skills, development skills, etc. Accountants are also shared and discussed. Being able to define Industry knowledge is one of the factors that helps accountants at work. Accountants have access to both corporate finance accounting, tax accounting, international financial reporting standards (IFRS), machine accounting, management accounting, career administrative accounting, and information systems. These courses are regularly updated, in accordance with current conditions.

However, the English ability of accountants needs to be improved in order to be able to study IFRS documents. Although accountants have learnt English for finance and accounting besides basic English, their English ability is still limited. However, accountants also have limitations such as weaknesses of accountants are the knowledge of temporary theory but the application is weak and lacking in general ability; do not know how to apply knowledge to solve systematic problems; group work is ineffective; lack of ability to manage and organize work.

The ability of accountants to work independently is quite good because it is one of the basic skills they have learned. However, there should be a combination of both independent and teamwork skills to handle your work well. Although working as a group of accountants still has some time when independence is needed to complete their work. Working independently is a skill that many employers mention when learning about an accountant. Accounting work requires both working in harmony and working independently to achieve good results. Accountants need to learn how to work focused, constantly seeking knowledge and interacting regularly with other colleagues. Confidence is a virtue, a quality that is needed in every human being. It is the key to success in life. Confidence helps people create a stable business. Self-confidence helps people to be brave in life, express themselves. Confidence will help to train their working skills, be assertive in every situation in life, help accumulate knowledge and experience. Selfconfidence helps people to have more strength, energy and creativity to make a great career. Confidence is always attractive to the trust of others. Your confidence will inevitably be showed in any job.

The experience of the accountants is to ensure whether the employees can meet the requirements of the job, this is the ability to complete work and real job skills. Experienced accountants have many positive impacts on new or inexperienced accountants. The experienced accountants are the teacher for the new accountant entering the job. Many firms value the importance of people to the success of firms, the human factor is considered as the center. Employees work in modern conditions, have opportunities for considerable development, and they are continuously trained with good treatment. Employees are engaged in a competitive environment as well as challenging their own abilities. With regular training courses, practical training is held domestically and abroad. Businesses bring opportunities to develop professional skills as well as career goals for their employees.

\subsubsection{Quantity and Quality of Accountants}

The number of qualified accountants who understand IFRS is very few. Moreover, they are not highly trained. IFRS requires Vietnamese accountants to be trained and supplemented with knowledge about IFRS. Furthermore, IFRS regular changes require the users update the information about it every year. IFRS is written in English. Therefore, the ability to read and apply IFRS of accounting staff at firms is one of the major barriers. IFRS has many complicated accounting terms so it is easy to cause misunderstandings and faults when it is translated into other languages. There are many English terms with no Vietnamese equivalent, especially in accounting. Therefore, accessing and understanding IFRS is very difficult.

However, this study has not fully presented (i) the framework for conversion of financial statements from Vietnamese accounting standards to IFRS, (ii) the manual conversion process of financial statements and (iii) the process of self-transformation of Financial Statements from Vietnamese Accounting Standards to IFRS. Therefore, we propose next research directions to overcome these limitations of this study, such as assessing the status of conversion of financial statements from Vietnam accounting standards to IFRS, the impact of IFRS application on enterprises in Vietnam, the impact of IFRS application on the curriculum of accounting majors at universities in Vietnam. 


\section{References}

Aisbitt, S. (2006). Assessing the Effect of the Transition to IFRS on Equity: The Case of the FTSE 100. Accounting in Europe, $3(1), 117-133$.

Barth, M. E. (2008). Global Financial Reporting: Implications for U.S. Academics. American Accounting Association, 83, 11591179.

Carlin, T. M., Finch, N., \& Tran, M. D. (2014). IFRS compliance in the year of the pig: Hong Kong impairment testing. Journal of Economics and Development, 16(1), 23-39.

Chalmers, K., \& Godfrey, J. M. (2004), Reputation costs: the impetus for voluntary derivative financial instrument reporting. Accounting, Organizations and Society, 29, 95-125.

Christensen, H. B., Lee, E., Walker, M., \& Zeng, C. (2015). Incentives or Standards: What Determines Accounting Quality Changes around IFRS Adoption? Europe Accounting Review, 24(3), 31-61.

Demaria, S., \& Dominique, D. (2008). First time adoption of IFRS, Fair value option, conservatism: Evidences from French listed companies. Retrieved August 7, 2019 from https://halshs.archives-ouvertes.fr/halshs-00266189.pdf.

Do, D. T., \& Tran, T. D. (2017). The influence of culture factor on the differences in the financial statement under Vietnam Accounting and international accounting: The case of FDI firms in Vietnam. Proceedings of national scientific workshop: Accounting - Auditing and Vietnam Economics with the industrial revolution 4.0. Qui Nhơn, Vietnam: Quy Nhon University.

Eva, K. J., \& Sylwia, G. T. (2007). Implementing IFRS from the perspective of EU publicly traded companies. Journal of International Accounting, Auditing and Taxation, 15, 170-196.

Eva, K. J., Alan, R., \& Natalie, T. C. (2014), IFRS frameworkbased case study: Daimler Chrysler - Adopting IFRS. Accounting Policies, 32, 288-304.

Francis, C., \& Hannah, W. (2010). The Effects of IFRS adoption on global capital market integration. Journal of International Business \& Economic Research, 9(10), 25-34.

Gray, S. J. (1988), Towards a Theory of Cultural Influence on the Development of Accounting Systems Internationally. Abacus, $24,1-15$.

Gray, J. S., Kang, T., Lin, Z., \& Tang, Q. (2015). Earning Management in Europe Post IFRS: Do Cultural Influences Persist? Management International Review, 55(6), 827-856.

Hair, J. F, Anderson, R. E., Tatham, R. L., \& Black, W. C. (2006). Multivariate data analysis. Upper Saddle River, NJ: PrenticeHall International Inc.

Hair, J. F., Black, W. C., Babin, B. J., \& Anderson, R. E. (2009). Multivariate Data Analysis (7th ed.). Upper Saddle River, NJ: Prentice Hall International.

Hoang, T., \& Chu, N. M. N. (2008). Analyzing researched d ata with SPSS (2 ${ }^{\text {nd }}$ ed.). Ho Chi Minh City, Vietnam: Ho ng Duc Publishing House.

Hofstede, G. (1980). Culture's consequences: International differences in work related values. Newbury Park, CA: Sage Publication.

Huynh, T. H., \& La, N. T. D. (2011). Determinants influencing the decision to choose workplace. Science Journal Can Tho University, 17b, 130-139.
Krzywda, D., \& Schroeder, M. (2007). An Analysis of the Differences between IFRS and Polish Accounting Regulations: Evidence from the Financial Statements of Listed Entities on the Warsaw Stock Exchange for the Calendar Years Ending 2001, 2003 and 2004. Journal Accounting in Europe, 4, 79107.

Irvine, H., \& Lucas, N. (2006). The rationale and impact of the adoption of international financial reporting standards on developing nations: the case of the United Arab Emirates. Proceedings of 18th Asian-Pacific Conference on International Accounting Issues (pp. 1-22).

Le, M. H. (2007). VAS 15 and IAS 11 about construction contracts - differences. Accounting Magazine, 8, 17-20.

Le, Q. P. (2017). Advantages and challenges in controlling inflation. Finance Journal, 3, 25-27.

Madawaki, A. (2012). Adoption of International Financial Reporting Standards in Developing Countries: The Case of Nigeria. International Journal of Business and Management, 7(3), 152-161.

Mantzari, E., Sigalas, C., \& Hines, T. (2017). Adoption of the International Financial Reporting Standard by Greek nonlisted companies: The role of coercive and hegemonic pressures. Accounting Forum, 41(3), 185-205.

Mizutani, F. (2016). The Relationship between Donor Behavior and Financial Statements in Japan. Journal of Asian Finance, Economics and Business, 3(4), 39-42.

Nguyen, C. P. (2017). Challenges and Solutions in Accounting Training in Applying IFRS. Proceeding of Scientific Seminar on Research and Training of Accounting and Auditing by Vietnamese Universities International Standards (pp. 31-38). Hanoi, Vietnam: National Economics University.

Nguyen, T. H. T. B., \& Lam, A. H. (2017). Financial Development, International Trade, and Stock Market Integration: Evidence in Six Southeastern Asia Countries. Journal of Economics and Development, 19(3), 5-17.

Nguyen, T. N. L., \& Nguyen, V. C. (2020). The Determinants of Profitability in Listed Enterprises: A Study from Vietnamese Stock Exchange. Journal of Asian Finance, Economics and Business, 7(1), 47-58.

Nguyen, T. T. H. (2018). The Impact of Financial Inclusion on Monetary Policy: A Case Study in Vietnam. Journal of Economics and Development, 20(2), 5-22.

Nguyen, T. T. P. (2014). Determinants influencing the application of IFRS in Vietnam [Master Thesis, University of Economics of Ho Chi Minh City].

Neel, M. (2017). Accounting Comparability and Economic Outcomes Mandatory IFRS Adoption. Contemporary Accounting Research, 34, 658-690.

Ocansey, E. O. N. D. (2014). Comparative study of the international financial reporting standard implementation in Ghana and Nigeria. European Scientific Journal, 10(13), $1857-7881$

Patel, C. (2003). Some cross-cultural evidence on whistle-blowing as an internal control mechanism. Journal of International Accounting Research, 2, 69-96.

Pham, D. C., (2016). The Difference between Vietnamese Accounting Law and International Law. Journal of Accounting and Auditing, 145, 84-89.

Ramanna, K. (2013). The international politics of IFRS 
harmonization. Accounting, Economics and Law, 3(2), 1-46.

Shima, K. M., \& Yang, D.C. (2012). Factors Affecting the Adoption of IFRS. International Journal of Business, 17(3), 1083-4346.

Shocker, A. D., \& Sethi, S. P. (1974). An approach to incorporating action preferences in developing corporate action strategies. California Management Review, 15(4), 97105.

Smith, M., \& Runyan, B. (2007). The effect of multi-nationality on the precision of management earnings forecasts. Inderscience Online, 4(6), 572-588.

Staubus, G. J. (2000). The decision-usefulness theory of accounting. New York, NY: Routledge Publishing Inc.

Struharo, K. (2010). Shift from National Reporting to Reporting in Accordance with International Financial Reporting Standard for Small and Medium-sized Entities and Its Effect on Financial Management - the Case of the Czech Republic. Journal of Competitiveness, 2, 74-89.

Taylor, Z. M. (1996), Spontaneous harmonization effects of culture and market forces on accounting disclosure practices. American Accounting Association, 10(1), 18-37.

Teller, T. R. (2009). First-Time Adoption of IFRS, Managerial
Incentives and Value- Relevance: Some French Evidence. American Accounting Association, 8, 1-22.

Tran, Q. T. (2013). Building Vietnam financial reporting standards to meet the trend of international accounting convergence [PhD thesis, University of Economics of Ho Chi Minh City].

Turel, A. (2009). The value relevance of IFRS: The case of Turkey. Finance and Banking, 5(1), 119-128.

Uzma, S. H. (2016). Cost-benefit analysis of IFRS adoption: Developed and emerging countries, Journal of Financial Reporting and Accounting, 14(2), 198-229.

Vo, T. T.A., Ha, X. T., \& Bui, P. N. K. (2018). What Causes Financial Crisis in Asian Countries? Journal of Economics and Development, 20(3), 5-19.

Yoon, K. H., Kim, B. U., \& Eom, J. G. (2014). The Effects of Job Crafting on Career Success of Multinational Corporations' Employees. Journal of Asian Finance, Economics and Business, 6(4), 213-225.

Zakari, M. A. (2014). Challenges of International Financial Reporting Standards (IFRS) Adoption in Libya. International Journal of Accounting and Financial Reporting, 4(2). [Online Journal] https://doi.org/10.5296/ijafr.v4i2.6302. 